\title{
The impact of agricultural cooperatives on efficiency and productivity: Evidence from olive-growing farms in West Bank of Palestine
}

\author{
KeNICHI KaSHIWAGI*
}

DOI: $10.30682 / \mathrm{nm} 2003 \mathrm{~b}$

JEL codes: O12, O13, Q13

\begin{abstract}
Collective action by farmers including the development of cooperatives is regarded as one of solutions to overcome low productivity. This study investigates the impact of agricultural cooperative on technical efficiency (TE) and total factor productivity (TFP) of olive farms in the West Bank of Palestine. Using cross-section data of olive-growing farms in Jenin Governorate, we estimated a stochastic frontier production function with inefficiency components. TFP was also estimated by residual approach. We employed propensity score matching to reduce self-selection bias in becoming a member of the cooperative. Results suggest that cooperative membership has a positive impact on TE and TFP, as joining a cooperative raises the TE by 10.16 to 10.52 percentage points. We interpret access to credits, land and productive olive seedlings, and extension services provided by cooperatives are possible pathways that affect TE and TFP. Due to the existence of huge inefficiency and low land productivity of olive farms in Jenin, we imply participation in cooperatives is an effective strategy for them to catch up with productive farms in the Mediterranean region.
\end{abstract}

Keywords: Agricultural cooperative, Technical efficiency, Total factor productivity, Propensity score matching, Olive-growing farms, West Bank.

\section{Introduction}

It is widely recognized that improving the productivity of smallholder farmers is one of the key strategies for rural development and poverty reduction. To improve productivity, one direction suggested by the efficiency studies is to realize the maximum possible output with the available resources and the given technology (Farrell, 1957; Battese and Coelli, 1995). The other is to induce technological innovation following changes in relative factor endowments (Hayami and Ruttan, 1985). Farmers need improved use of improved inputs and better access to agricultural technology and markets to optimize technical efficiency (TE) with the limited available resources, not only for the realization of frontier output but also the shift in production frontier. The agriculture sector in the arid and semi-arid Mediterranean region often operates under multiple constraints, such as small plot sizes and harsh climatic conditions. Hence, improving TE with available inputs is critical to raising agricultural productivity. However farmers in this

\footnotetext{
* Faculty of Humanities and Social Sciences, Alliance for Research on the Mediterranean and North Africa (ARENA), University of Tsukuba, Tsukuba, Ibaraki, Japan.

Corresponding author: kashiwagi.kenichi.fn@u.tsukuba.ac.jp
} 
region face numerous constraints, including unstable production and limited access to modern inputs, credit, and export markets. Most farmers end up having less incentive to invest in farming, which hinders opportunities for productivity growth and efficiency improvement.

Currently, the role of farmers' organizations including agricultural cooperatives has become increasingly important in supporting farmers' collective action. Agricultural cooperatives are important rural organizations that assist livelihood development and poverty reduction (Getnet and Anullo, 2012; Abebaw and Haile, 2013; Wossen et al., 2017). Donors and policymakers have revived their policy interest on promoting rural collective action (World Bank, 2007; Bernard et al., 2008). Policies promoting collective action including cooperatives are regarded as ways to improve market access for smallholder farmers in the developing world (Francesconi and Heerink, 2011). As in many developing countries, cooperatives in the Mediterranean region are important organizations that support smallholder farmers as well as micro and small enterprises (Iliopoulos, 2005; López and Marcullo, 2006; Ozalp, 2019). To overcome constraints under severe semi-arid climates, farmers' organizations such as agricultural cooperatives and water users' associations play a major role in the production, distribution, and marketing of agricultural products.

In the Mediterranean region, agriculture under Israeli occupation is one of the severe challenges faced by Palestinian farmers. Since 1967, when the area was occupied by Israel, Palestinian agriculture has not only been constrained by weather conditions but also by geographical and political factors. Under these constraints, Palestinian farmers' organizations such as agricultural cooperatives play a major role. According to the State of Palestine Ministry of Agriculture (MOA), there are currently 610 cooperatives, of which 283 are agricultural cooperatives. Agricultural cooperatives support farmers in various fields such as livestock management, grain production, rural finance, and technical support services. Through agricultural cooperatives, the Ministry extends technical assistance, improvement and spread of agriculture, and agricultural inputs such as seeds, seedlings, and fertilizers. Member farmers have benefited from various aspects in the value chain, including access to modern input goods, development of water storage, provision of irrigation facilities, developing and selling processed agricultural products, and expanding sales channels. In Palestine, the role of agricultural cooperatives is becoming increasingly important, especially for smallholder farmers.

Given these conditions, the objective of this study is to investigate the impact of agricultural cooperatives on the efficiency and productivity of olive-growing farms. Currently, national development strategies regard olive as one of the main subsectors in Palestinian agriculture. The specific role of the olive and olive oil sector was addressed not only in the Agriculture Sector Strategy "Shared Vision" of 2011-2014, but also in the Agricultural Sectoral Strategy "Resilience and Development" of 2014-2016. The MOA formulated a "National Strategy for Olive and Olive Oil Subsector in Palestine" in 2014 in line with the Agricultural Sectoral Strategy. The role of agricultural cooperatives was addressed to improve productivity, competitiveness, and efficiency in the olive oil value chain. In view of the strategic significance of the olive and olive oil sector for Palestinian agricultural development, we implemented a survey entitled "Survey of Olive Farms in the West Bank, Jenin" during September 2015 and 2016. We collaborated with the Palestinian Central Bureau of Statistics (PCBS) to collect household data from olive-growing farms in Jenin of the West Bank.

Using this micro-data, we estimated TE by employing the stochastic frontier production function. In addition, we estimated total factor productivity (TFP) by using residual approach of production function. Technical inefficiency is measured by the distance between maximum possible output and observed output. The reduction of this distance, i.e., efficiency improvement, shows the movement of the farms' actual output toward its maximum possible output (production frontier) with given technology. On the other hand, we measure TFP as a residual, i.e., growth of output which is not explained by inputs growth. The growth of TFP suggests an upward shift in the farm's production frontier, 
i.e., technical change. Investigation on the level of TE and the potential of technical change is relevant for economic evaluation on productivity. Also, detecting factors that affect TE and technical change suggest policy implications to enhance farms' productivity.

Plenty of efficiency studies have been applied to olive-growing farms and olive oil manufactures, but the relationship between membership in agricultural cooperatives and efficiency has not yet been examined (Lambarraa et al., 2007; Amores and Contreras, 2009; Tzouvelekas et al., 1999; Karagiannis and Tzouvelekas, 2001; Tzouvelekas et al., 2001; Cukur et al., 2013; Artukoglu et al., 2010; Lachaal et al., 2004; Lachaal et al., 2005; Kashiwagi et al., 2016). Apart from the olive sector, several studies have investigated the impact of membership in an agricultural cooperative on efficiency by applying the stochastic frontier approach. Chirwa (2003) estimated the level of TE among smallholder maize farmers in Malawi. This study found that smallholder maize farmers in Malawi are inefficient, but it revealed that inefficiency falls after joining a farmer club or association. In the slashand-burn zone of Cameroon, Binam et al. (2005) found that membership in a farmers' club or association has a positive impact on TE. Idiong (2007) investigated TE of small-scale swamp rice farmers in Nigeria's Cross River State. This study suggested that membership in a cooperative farmers' association is related to higher TE and positively influenced the farmers' efficiency. For small wheat farmers in Chile, Jaime and Salazar (2011) found that joining cooperatives and gremial associations influenced the farmers' TE positively. By applying data envelopment analysis, Chebil et al. (2015) found that irrigated wheat farmers in Tunisia who joined water users' associations were positively affected in terms of technical and economic efficiency. These studies confirmed that membership in an agricultural cooperative has a positive impact on TE.

Following the above-mentioned studies, we compare estimated TE and TFP between cooperative members and non-members. However, the estimated parameters of production function and these performance measures may be affected by a self-selection mechanism for choosing whether or not to join a cooperative. Considering the potential bias caused by self-selection in the choice of membership, we apply propensity score matching (PSM). The PSM technique control selection bias emerged by a farm's choice to join a cooperative (Mayen et al., 2010; Bravo-Ureta et al., 2012; Anang et al., 2016).

Due to the possible endogenous decision of joining a cooperative, several studies employed the PSM technique to examine the impact of agricultural cooperatives. For smallholders in Ethiopia, Bernard et al. (2008) examined the impact of cooperatives on household market participation and the crop prices households obtained in the market. By controlling possible self-selection bias, they found that cooperative members managed to secure a higher price for their products. Francesconi and Heerink (2011) found Ethiopian farmers belonging to marketing cooperatives showed significantly higher commercialization rates compared with non-member farmers. Regarding adoption of agricultural technologies by Ethiopian farmers, Abebaw and Haile (2013) suggested that cooperative membership has a strong and positive impact on fertilizer adoption, but not on adoption of improved seeds and pesticides. Getnet and Anullo (2012) found a positive impact of agricultural cooperatives on rural household income, savings, agricultural input expenditures, and asset accumulation in Ethiopia. Employing PSM and switching regression approach for farmers in rural Nigeria, Wossen et al. (2017) suggested that becoming a cooperative membership positively affects technology adoption and access to formal credit.

Most studies suggest a positive impact of agricultural cooperative membership on commercialization, market participation, adoption of technology, and access to modern inputs. However, few studies have examined the impact of agricultural cooperatives on TE and TFP. Abate et al. (2014) applied PSM to compare the difference of TE between cooperative members and non-members in Ethiopia but did not test for TFP. In our previous study, Kashiwagi (2017) estimated TE using a sample of olive-growing farms in Jenin collected during 2015, but the impact of cooperative membership was not examined. Therefore, this study tried to go one step 
further by investigating the impact of cooperative and by increasing the number of samples collected from 2015 to 2016 . What is more, we employ the PSM method to mitigate the endogenous bias caused by the decision to join a cooperative. To our knowledge, there are no studies that have examined the effect of agricultural cooperatives on the efficiency and productivity of olive farms.

The remainder of the study is organized as follows. The next section reviews recent developments of agricultural cooperatives in Palestine. In Section 3, we explain the model used in this study. Data collection for estimation is presented in Section 4. We present the empirical results in Section 5. Section 6 extends the discussion. Section 7 concludes this study.

\section{Agricultural cooperatives in Palestine: recent development}

The history of agricultural cooperatives in Palestine dates back to the period under the British Mandate. While informal cooperatives existed because of strong traditional family and community ties, the first official cooperative was established in 1924. In 1933, the first law for cooperatives was issued. Up until 1948, 244 cooperatives were registered, most of which engaged in agriculture, rural development, and transportation. The number of cooperatives increased to 487 in the West Bank and Gaza Strip during the 1950s and 1960s. Just before the Six Day War in 1967, there were 418 registered cooperatives in the West Bank and 719 in the East Bank under the Kingdom of Jordan (MOA, 2015). After 1967, cooperatives in the West Bank and Gaza Strip continued to exist under the Israeli occupation. A set of restrictions and procedures imposed by the Israeli authorities hindered farmers' collective actions, including cooperative activities. However, Arab and international organizations continued to assist cooperatives in the West Bank and Gaza Strip (MOA, 2015).

According to the ILO, there are 230 agricultural cooperatives in the West Bank, working mainly in five sectors: animal husbandry (32\%), crop production (29\%), agricultural services $(25 \%)$, olive and olive oil production and press- ing (10\%), and rural development, saving, and credit (4\%) (ILO, 2014). There are 35 cooperatives dealing with cultivation of olives and production of olive oil in the West Bank. There are 107 agricultural cooperatives and societies specializing in plant and olive trees (MOA, 2014). The total number of cooperative members in the West Bank reached 18,685, and $16.5 \%$ of these are concentrated in the olive and olive oil sector. The number of members per cooperative engaged in olive farming and olive oil extraction is the highest at about 140 (ILO, 2014).

Agricultural cooperatives provide various services related to food processing, marketing, extension, and development to their members, including supply of modern inputs (e.g., seeds, fertilizers, irrigation, and machinery) and collective purchasing products. They also provide services for savings and credit to their members who have less access to financing for working capital and investments. Animal husbandry cooperatives provide services of animal breeders for marketing, feed, and provision of modern inputs (ILO, 2014). Agricultural cooperatives and associations support the various processes of production by working as advisory councils and contributing to reduce the costs of inputs of members through the purchase of shared agricultural machinery (ARIJ, 2015). The Ministry of Agriculture provides technical support, extension, provision of modern inputs such as seeds, seedlings, and fertilizers, and irrigation equipment to the members of cooperatives (MOA, 2015). The Ministry involves cooperatives in implementing several projects, including land development, development of high value-added agro-food products, and expansion of export destinations through the provision of agricultural services.

As noted, the MOA formulated the national strategy for the olive and olive oil subsector in Palestine. Specific objectives of this strategy addressed the need for farmers' associations and cooperatives to be better capacitated and to interact seamlessly with the private sector. Under this national strategy, the Ministry proposed an action plan spanning a five-year period from 2014 to 2019. In the second phase of the program, which targets increased efficiency of post-har- 
vesting activities and marketing systems, one of the objectives aims at supporting olive oil cooperatives and the private sector to improve their marketing capabilities and involvement in negotiations and trade talks with other partners (MOA, 2014). Despite the increasing role of cooperatives, challenges remain, including weak relations between state and cooperatives, weak cooperative spirit (cooperative principles and values) among cooperatives, weak representation, weak administration and financial skills, and donor dependency (MOA, 2015). According to the report prepared by the Applied Research Institute-Jerusalem (ARIJ), the percentage of farmers belonging to agricultural cooperatives and associations remained at only 33\% (ARIJ, 2015). Regardless of these challenges, the development of farmers' organizations is effective in coping with problems that are difficult to overcome by individual farmers' efforts alone. The role of agricultural cooperatives is increasingly important to stabilize production and expand access to the international market, especially in Palestine, where there are various constraints on agricultural development.

\section{Model}

\subsection{Stochastic frontier production function and technical efficiency}

We estimate TE from cross-sectional data of olive-growing farms, applying the model of stochastic frontier production (SFP) function. Following Aigner et al. (1977), and Meeusen and van den Broeck (1977), Battese and Coelli (1995), we employ a parametric approach to estimate TE. For simplicity of the analysis, we assume a Cobb-Douglas form of SFP:

$$
\ln y_{i}=\beta_{0}+\sum_{j=K, L, F, W}^{W} \beta_{j} \ln x_{i j}+v_{i}-u_{i},
$$

where $y_{i}$ represents the quantity of olive production measured in $\mathrm{kg} ; \beta_{0}, \beta_{j}(j=K, L, F, W)$ are the unknown parameters to be estimated; $x_{K i}$ is the capital stock used for olive cultivation measured in new Israeli shekel (NIS); $x_{L i}$ is the land area where olive trees are planted (measured in ha); $x_{F i}$ is the number of total family labour en- gaged; $x_{W i}$ is the number of total wage labour employed for olive production. The error term is divided into two parts: $v_{i}$ denotes statistical random disturbance terms assumed independently and identically distributed, i.e., $v_{i} \sim$ iid $N\left(0, \sigma_{v}{ }^{2}\right)$, and $u_{i}$ is the one-sided non-negative random disturbance term, assuming independently and identically distributed with a half-normal distribution at zero mean, i.e., $u_{i} \sim$ iid $N^{+}\left(0, \sigma_{u}^{2}\right)$ (Aigner et al., 1977). Regarding distributional assumption on $u_{i}$, Meeusen and van den Broeck (1977) assigned an exponential distribution, and Jondrow et al. (1982) considered both a half-normal and an exponential distribution.

From Equation (1), TE of the $i$ th farm is given by $T E_{i}=\exp \left(-u_{i}\right)$. The technical inefficiency effect, $u_{i}$, in the stochastic frontier model is specified as follows:

$$
u_{i}=\boldsymbol{z}_{i}^{\prime} \boldsymbol{\delta}+\mu_{i}
$$

where $\delta$ is a vector of the unknown parameters to be estimated; $\boldsymbol{z}_{i}$ is a vector of explanatory variables associated with technical inefficiency in production; $\mu_{i}$ is a remaining random variable.

We estimate SFP simultaneously with inefficiency effect model by directly inserting explanatory variables into the inefficiency components (Kumbhakar et al., 1991; Huang and Liu, 1994). The technical inefficiency components $\left(u_{i}\right)$ are defined as:

$$
u_{i}=\delta_{0}+\sum_{h=1}^{H} \delta_{h} z_{h i}+\mu_{i}
$$

where $z_{h i}(h=1,2, \ldots, H)$ represents variables which explain the variation of technical inefficiency; $\delta_{0}, \delta_{h}(h=1,2 \ldots, H)$ are unknown parameters to be estimated; $\mu_{i}$ is a random disturbance term.

\subsection{Total factor productivity (TFP)}

TFP is commonly used as a measure of firms' productivity. A higher TFP is associated with higher productivity. In the first step, we measure farm-level TFP as a residual of production function (Baily et al., 1992; Bartelsman and Dhrymes, 1998). In the second, TFP is regressed on several explanatory variables to find its deter- 
minants. We use the Cobb-Douglas production function specified as follows:

$$
\ln y_{i}=\ln A_{i}+\sum_{j=K, L, F, W}^{W} \theta_{j} \ln x_{i j},
$$

where $A_{i}$ equals an index of TFP; $\theta_{j}$ represents the production elasticity with respect to each input factors. $A_{i}$ represents an indicator that captures the technical change of $i$ th farm. The log of TFP index is the residual term obtained by estimating coefficients of production function of Equation (4). TFP can be calculated as residual:

$$
\ln A_{i}=\ln y_{i}-\sum_{j=K, L, F, W}^{W} \hat{\theta}_{j} \ln x_{i j}
$$

where $\hat{\theta}_{j}$ are estimated coefficients. The estimated TFP is regressed to examine the impact of being cooperative members on technical change. The model of TFP equation could be specified as follows:

$$
\ln A_{i}=\lambda_{0}+\sum_{h=1}^{H} \lambda_{h} F_{h i}+\varepsilon_{i},
$$

where $F_{h i}(h=1,2, \ldots, H)$ is the farm-specific variables which affect TFP; $\lambda_{0}, \lambda_{h}(h=1,2 \ldots, H)$ are unknown parameters to be estimated; $\varepsilon_{i}$ is a random error term.

\subsection{Propensity score matching (PSM)}

We quantify the effect of cooperative membership on efficiency and productivity of farmers using cross-sectional data. The counterfactual approach of causality proposed by Heckman et al. (1997) cannot be employed, as becoming a member of a cooperative is not randomly assigned. In the absence of random assignments, selection bias may exist since unobserved characteristics of individual farmers may affect their productivity. We employ the PSM technique to mitigate the bias due to self-selection (Rubin, 1977; Rosenbaum and Rubin, 1983). The PSM method assumes that conditioning on observable variables eliminates sample selection bias (Heckman and Navarro-Lozano, 2004; Mayen et al., 2010). Its basic idea is to match each treated farm with a similar untreated farm, by identifying non-members of cooperative who have similar observable characteristics with members.
Following Rosenbaum and Rubin (1983), Dehejia and Wahba (2002), Abebaw and Haile (2013), we estimate the predicted probability that a farm becomes a member of a cooperative, i.e., the propensity score. Thus, the propensity score is defined as follows:

$$
p(\boldsymbol{Z})=\operatorname{Pr}\left\{C_{i}=1 \mid \boldsymbol{Z}\right\}=E\left\{C_{i} \mid \boldsymbol{Z}\right\},
$$

where $C_{i}=\{0,1\}$ denotes the treatment variable ( 1 if a farm become a cooperative member, 0 otherwise); $E$ is the expected value; $\boldsymbol{Z}$ represent a vector of pre-treatment characteristics of farms. From Equation (7), we estimate propensity scores by applying the logit model. This binary model is assumed to be a function of observed characteristics $(\boldsymbol{Z})$ :

$$
\begin{aligned}
& C_{i}^{*}=Z_{i}^{\prime} \gamma+e_{i}, \\
& C_{i}= \begin{cases}1 & \text { if } C_{i}^{*}>0 \\
0 & \text { if } C_{i}^{*} \leq 0\end{cases}
\end{aligned}
$$

where $C_{i}^{*}$ is unobserved continuous variable of cooperative membership; $\boldsymbol{\gamma}$ is a vector of unknown parameter to be estimated, and $e_{i}$ is random disturbance term in the logit equation. The dependent variable, $C_{i}$, is observable and equals 1 if a farm becomes a member of cooperatives and 0 otherwise. Regarding the choice of explanatory variables included in $\boldsymbol{Z}_{i}$, we follow previous empirical literatures (Bernard et al., 2008; Abebaw and Haile, 2013; Wossen et al., 2017). The variables include age, education, years of farming, age of olive trees, number of olive trees, number of irrigated trees, number of family and wage labor, and distance to the nearest olive oil mill. As sample farms may not be randomly distributed between cooperative members and non-members, observable farms' attributes including age, education and years of farming of household head are significant factors to control the farms' heterogeneity. We assume the elder and educated farmers having experience may have higher probability to become cooperative members. Age of olive trees and number of trees planted with given plot of land, access to irrigation and share of wage labour are also important observable characteristics of farms. While we did not assume signs of 
parameters of age and number of trees a priori, the assumption maintained here is farms having more access to irrigation and employing more wage labour associate with higher probability to be members. Distance to the nearest oil mill may be exogenous given condition but it is included to control the location of individual farms. Farms in remote areas may have less possibility to become a member.

Assuming that firms have two potential productivity outcomes, $Y_{i}$, given membership of cooperative $\left(C_{i}\right)$ such that $Y_{i}=Y_{0 i}$ if $C_{i}=0$ and $Y_{i}$ $=Y_{1 i}$ if $C_{i}=1$. Following Imbens and Wooldrige (2009), the average treatment effect on the treated (ATT) is specified as:

$$
\begin{aligned}
& A T T=E\left(Y_{1 i}-Y_{0 i} \mid \boldsymbol{Z}, C_{i}=1\right)= \\
& E\left(Y_{1 i} \mid Z, C_{i}=1\right)-E\left(Y_{0 i} \mid Z, C_{i}=1\right),
\end{aligned}
$$

where $Y_{0 i}$ represents farm's productivity of non-member $\left(C_{i}=0\right) ; Y_{1 i}$ represents farm's productivity of member $\left(C_{i}=1\right)$. We can observe $E\left(Y_{1 i} \mid \boldsymbol{Z}, C_{i}=1\right)$ in our dataset, but cannot observe the average outcome of $Y_{i}$ that the treatment group would have obtained in the absence of treatment. The counterfactual, $E\left(Y_{0 i} \mid \boldsymbol{Z}, C_{i}=1\right)$, is not readily available, but the propensity score can create comparable counterfactual farms to match farms with cooperative membership. Once farms are matched with their counterfactuals, the PSM method assumes that systematic differences in unobservable characteristics do not exist between the two groups. Assuming this conditional independence, $A T T$ is expressed as:

$$
\begin{aligned}
& A T T=E\left(Y_{1 i} \mid C_{i}=1, p(\boldsymbol{Z})\right)- \\
& E\left(Y_{0 i} \mid C_{i}=0, p(\boldsymbol{Z})\right),
\end{aligned}
$$

where $p(\boldsymbol{Z})$ is the propensity score, i.e., the likelihood of becoming a member of a cooperative based on observable characteristics of farms. This equation allows an unbiased estimation of ATT of becoming a member of a cooperative.

\section{Data}

The source of data used in the estimation is taken from the "Survey on Olive Farms in West Bank, Jenin." We implemented this survey with the PCBS in September 2015 and October 2016. We chose Jenin Governorate since it has the largest area and number of olive trees in the West Bank. The Jenin Governorate is at the northernmost end of the West Bank. The Population and Housing Census 2007 by the PCBS indicates the Governorate had a population of 314,866 with a total of 65,539 households (PCBS, 2017). In the entire West Bank, the total area of horticulture trees was 47,370 ha in 2010 , of which olive cultivation occupies $88.6 \%$. The area under olive cultivation in the West Bank was 41,979 ha, where $6,743,149$ olive trees were planted in 2010 (PCBS, 2012a). Jenin Governorate occupies $17.9 \%$ of the cultivated area of horticulture trees of the West Bank in 2010-2011 (PCBS, 2012a). In Jenin, the total area under olive cultivation was 9,202 ha with $1,404,932$ trees (PCBS, 2012b). The production of olives in 2009-10 was the highest in Jenin with 16,741 tons of olives produced (MOA, 2014). Despite having the highest production, the average land productivity of Jenin stagnated compared with other governorates. These facts suggest the necessity of improving productivity in Jenin. The number of samples collected in this survey was 354 olive-growing farms which are distributed by strata design. We employed one-stage stratified random sampling, and the rate of response was $89.5 \%$. Due to the missing information on age and distance to the nearest olive mill, four samples were dropped. This left 350 samples of the cross-section data olive farms for the empirical analysis. In this sample, 76 farms are members of an agricultural cooperative (treatment group), representing $21.7 \%$ of the sample, and the remaining 274 farms $(78.3 \%)$ are non-members (control group).

Table 1 presents the descriptive statistics of the variables, including the comparison of mean values between members of agricultural cooperatives and non-members. The mean level of the production, capital stock, land area and wage labour are significantly higher in cooperative members than non-members. Capital stock includes four-wheel tractors, track-laying tractors, cultivators, rotary tillers, sprayers, water-tanks, water-pumps, trailers and ploughs, but not incudes buildings. These figures suggest that farms 
Figure 1 - Distribution of propensity score among cooperative member farms and non-member farms.

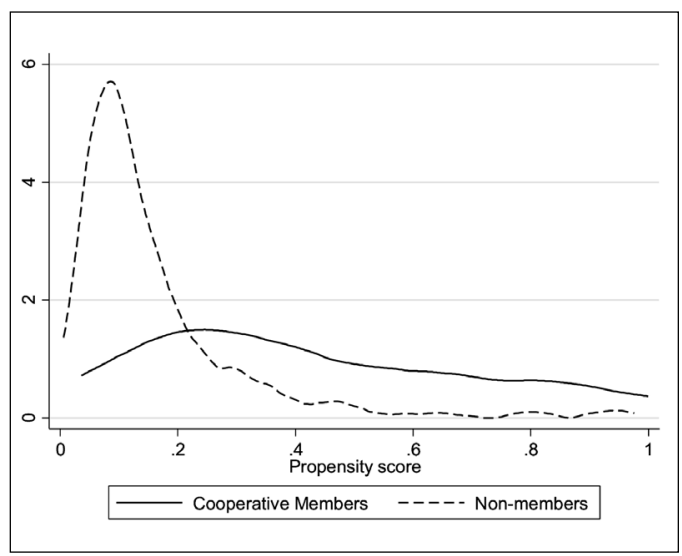

belonging to agricultural cooperative are relatively larger in size. Thus, they are more likely to employ outside wage labor. The density of olive trees of non-members is significantly higher than members, which suggests that cooperative members are less likely to adopt intensive farm- ing. This result may reflect the size of land holdings. Smallholders may adopt intensive cultivation due to their limited land size. On average, the age of olive trees and share of irrigated area are lower for members than for non-members, but the differences of the two groups are not statistically significant.

\section{Empirical results}

\subsection{Estimation of propensity scores}

The estimated coefficients and standard errors of the logit model are presented in Table 2. The dependent variable equals 1 for cooperative members and 0 for non-members. This logit model correctly predicts $83.7 \%$ of the sample observations. The high value of c-statistics suggest that the condition of the strong ignorable treatment assignment is maintained. Several explanatory variables included in this model have a significant effect on the decision to join cooperatives. The area of farmland is positively

Table 1 - Descriptive statistics of sample farm households.

\begin{tabular}{|l|rr|rr|c|}
\hline & Members $(n=76)$ & Non-members $(n=274)$ & \multirow{2}{*}{$\begin{array}{c}\text { Mean } \\
\text { difference }\end{array}$} \\
\cline { 2 - 5 } & Mean & $\begin{array}{c}\text { Standard } \\
\text { deviation }\end{array}$ & Mean & $\begin{array}{r}\text { Standard } \\
\text { deviation }\end{array}$ & \\
Production (kg) & 7548.6 & 6820.7 & 2580.7 & 4175.9 & $4968.0^{* * *}$ \\
Capital stock (thousand NIS) & 7.8 & 11.7 & 3.0 & 7.8 & $4.774^{* * *}$ \\
Land (ha) & 4.8 & 3.5 & 1.8 & 2.1 & $3.042^{* * *}$ \\
Family labour (number) & 4.6 & 4.0 & 4.4 & 3.9 & 0.248 \\
Wage labour (number) & 4.8 & 4.6 & 3.5 & 5.9 & $1.305^{*}$ \\
Land-labour ratio (ha/labour) & 0.614 & 0.060 & 0.236 & 0.016 & $0.378^{* * *}$ \\
Percentage of farms using fertilizer (\%) & 46.1 & 50.2 & 39.8 & 49.0 & 6.272 \\
Age of household head (years) & 56.5 & 12.2 & 54.5 & 12.1 & 1.976 \\
Years of education of household head (years) & 12.8 & 4.6 & 12.3 & 5.0 & 0.490 \\
Years of farming (years) & 23.7 & 11.5 & 21.6 & 13.2 & 2.036 \\
Age of olive trees (years) & 38.5 & 20.8 & 42.0 & 26.2 & -3.570 \\
Total number of trees (number) & 664.4 & 476.9 & 271.4 & 331.2 & $393.0^{* * *}$ \\
Total number of irrigated trees (number) & 57.6 & 146.5 & 18.3 & 55.4 & $39.3^{* * *}$ \\
Density of olive trees (number/ha) & 145.4 & 45.3 & 155.7 & 36.9 & $-10.3^{* *}$ \\
Share of irrigated area (\%) & 7.2 & 13.1 & 8.0 & 18.1 & -0.828 \\
Distance to nearest oil mill (km) & 5.1 & 6.8 & 4.1 & 4.5 & 0.960 \\
\hline
\end{tabular}

Notes: NIS indicates new Israeli shekel. *, **, *** indicate significant at the 10\% level, 5\% level, $1 \%$ level, respectively. 
Table 2 - Estimated coefficients and standard errors of logit model of the determinants of being cooperative member.

\begin{tabular}{|l|c|c|}
\hline \multicolumn{1}{|c|}{ Variable } & Coefficient & Standard error \\
\hline Constant & -3.0736 & 2.5328 \\
Capital stock & 0.0140 & 0.0152 \\
Land & $0.6423^{* * *}$ & 0.1702 \\
Family labour & -0.0222 & 0.0406 \\
Wage labour & $-0.0702^{* *}$ & 0.0319 \\
Age & -0.0759 & 0.0906 \\
Age squared & 0.0009 & 0.0008 \\
Years of education & 0.0237 & 0.0381 \\
Years of farming & $0.1020^{* *}$ & 0.0485 \\
Years of farming squared & $-0.0022^{* *}$ & 0.0009 \\
Age of olive trees & $0.0462^{*}$ & 0.0278 \\
Age of olive trees squared & $-0.0005^{*}$ & 0.0003 \\
Total number of olive trees & -0.0014 & 0.0012 \\
Total number of irrigated olive trees & $0.0042^{*}$ & 0.0023 \\
Distance to nearest oil mill & 0.0355 & 0.0293 \\
& & \\
Log-likelihood & -138.578 & \\
$\chi{ }^{2}(14)$ & 89.13 & \\
Percentage correctly predicted & 83.70 & \\
Pseudo $R^{2}$ & 0.243 & \\
c-statistics & 0.839 & \\
Number of observations & 350 & \\
\hline
\end{tabular}

Note: *,**, *** indicate significant at the $10 \%$ level, $5 \%$ level, $1 \%$ level, respectively.

related to access to cooperatives. This suggests that large farms are more likely to participate in cooperative activities. Yet, a negative sign of parameter of wage labour suggests that increased employment of wage labour is negatively related to the probability of being a member. Years of farming and age of olive trees have a significant and non-linear effect on cooperative membership. The probability of joining a cooperative increases along with farm age. Similarly, the likelihood of joining a cooperative increases along with age of trees. While the coefficient of number of all trees is not significant, increase in number of irrigated trees has a negative and significant effect on probability of being a cooperative member. Farms with expanded irrigation are also more likely to be cooperative members.

The estimated coefficient of wage labour is negative, while its mean value is significantly higher for members than non-members (Table 1). These results suggest farms with more wage labour are less probability to become cooperative members, if we control farm's characteristics. So, we run auxiliary logit regressions with interaction terms between capital stock/land and wage labour. We found a negative and significant coefficient of the interaction between wage labour and land. This result suggests probability to become cooperative members mostly affected by both land holdings and wage employment. The average number of wage labour in higher in cooperative members than non-members, yet large farms who employ more wage labour are less like to become cooperative members.

By using these covariates, we estimated the propensity score for each farm as the predicted probability of being a cooperative member. Figure 1 presents the distribution of propensi- 
Table 3 - Balancing test of matched sample.

\begin{tabular}{|c|c|c|c|c|c|c|c|c|c|}
\hline \multirow[t]{3}{*}{ Variable } & \multicolumn{3}{|c|}{$\begin{array}{l}\text { Unmatched } \\
\text { samples }\end{array}$} & \multicolumn{3}{|c|}{$\begin{array}{l}\text { Kernel } \\
\text { matching }\end{array}$} & \multicolumn{3}{|c|}{$\begin{array}{c}\text { Five nearest neighbors } \\
\text { matching }\end{array}$} \\
\hline & \multicolumn{2}{|c|}{ Mean } & \multirow{2}{*}{$\begin{array}{c}\text { Diff: } \\
P>|t|\end{array}$} & \multicolumn{2}{|c|}{ Mean } & \multirow{2}{*}{$\begin{array}{c}\text { Diff: } \\
P>|t|\end{array}$} & \multicolumn{2}{|c|}{ Mean } & \multirow{2}{*}{$\begin{array}{c}\text { Diff: } \\
P>|t|\end{array}$} \\
\hline & Treated & Control & & Treated & Control & & Treated & Control & \\
\hline Capital stock & 7.786 & 3.012 & 0.000 & 6.747 & 6.458 & 0.871 & 7.007 & 6.565 & 0.812 \\
\hline Land & 4.813 & 1.771 & 0.000 & 4.241 & 4.185 & 0.908 & 4.053 & 4.213 & 0.746 \\
\hline Family labour & 4.632 & 4.383 & 0.624 & 4.389 & 4.827 & 0.509 & 4.672 & 4.636 & 0.958 \\
\hline Wage labour & 4.816 & 3.511 & 0.078 & 4.639 & 5.153 & 0.594 & 4.209 & 5.391 & 0.238 \\
\hline Age & 56.487 & 54.511 & 0.209 & 56.875 & 56.782 & 0.962 & 55.627 & 56.645 & 0.597 \\
\hline Age squared & 3338.4 & 3116.4 & 0.233 & 3387.7 & 3337.8 & 0.828 & 3227.1 & 3319.0 & 0.681 \\
\hline Years of education & 12.829 & 12.339 & 0.445 & 12.792 & 13.092 & 0.711 & 13.060 & 13.581 & 0.515 \\
\hline Years of farming & 23.671 & 21.635 & 0.221 & 24.250 & 23.657 & 0.750 & 23.388 & 23.648 & 0.892 \\
\hline $\begin{array}{l}\text { Years of farming } \\
\text { squared }\end{array}$ & 691.6 & 640.4 & 0.582 & 716.890 & 675.100 & 0.691 & 669.2 & 679.1 & 0.926 \\
\hline Age of olive trees & 38.474 & 42.044 & 0.274 & 37.431 & 36.438 & 0.778 & 36.896 & 36.610 & 0.937 \\
\hline $\begin{array}{l}\text { Age of olive trees } \\
\text { squared }\end{array}$ & 1908.1 & 2451.6 & 0.113 & 1823.7 & 1778.9 & 0.894 & 1791.8 & 1764.0 & 0.936 \\
\hline $\begin{array}{l}\text { Total number of } \\
\text { olive trees }\end{array}$ & 664.5 & 271.4 & 0.000 & 591.7 & 600.0 & 0.912 & 579.6 & 603.8 & 0.752 \\
\hline $\begin{array}{l}\text { Total number of } \\
\text { irrigated olive trees }\end{array}$ & 57.566 & 18.281 & 0.000 & 42.250 & 33.253 & 0.517 & 39.791 & 36.230 & 0.806 \\
\hline $\begin{array}{l}\text { Distance to nearest } \\
\text { oil mill }\end{array}$ & 5.050 & 4.090 & 0.146 & 5.039 & 6.037 & 0.366 & 5.125 & 5.178 & 0.962 \\
\hline
\end{tabular}

Notes: treated are cooperative members. Samples limited to common support region.

ty scores based on kernel density estimates for members and non-members. As expected, the distributions of propensity score are not similar between the two groups. The mean value of propensity scores of the all sample is estimated at $0.217(\mathrm{SD}=0.217)$, ranging from 0.005 to 0.999 . With a mean score of $0.435(\mathrm{SD}=0.278)$, the propensity scores of cooperative members vary between 0.036 and 0.999 . That of a non-member is estimated at $0.156(\mathrm{SD}=0.148)$, ranging from 0.005 to 0.975 . As shown in Figure 1 , the distribution of non-member farms is skewed toward zero. It suggests that matching is necessary to assure the robustness of our estimations. We apply broadly used methods, i.e., Kernel matching and five nearest neighbors match- ing. We restrict the sample under the common support region. The propensity scores of those two groups mostly overlap, but four to nine observations were dropped due to off support. We implemented a balancing test of the matched sample to check whether the balancing requirements of PSM are maintained. The results of the balancing test based on Kernel and five nearest neighbors matching are reported in Table 3 . The unmatched sample does not satisfy the balancing property as the two groups are comparable in 9 out of 14 covariates. However, after matching, the two groups have no statistically significant differences in observed covariates. These results suggest the balancing test requirements are satisfied (Rosenbaum and Rubin, 1985). 


\subsection{Estimation of TE and TFP}

The Kernel matching technique produced a subsample of 346 farms under common support, comprising 72 members and 274 non-members. In matching the five nearest neighbors, a subsample of 343 farms was produced (69 member farms, 274 non-member farms). We used all samples and new sub-samples for the estimation of a production frontier. Table 4 presents estimated coefficients and standard errors of SFP model with inefficiency components. Maximum likelihood estimators were obtained, assuming the one-sided error term $\left(u_{i}\right)$ has a half-normal distribution. We rejected the null hypothesis of the absence of inefficiency effects by the likelihood-ratio (LR) test $\left(\sigma_{u}=0\right)$. In the inefficiency components, LR-test rejected the null hypothe-

Table 4 - Estimated coefficients and standard errors of SFP finction with inefficiency components.

\begin{tabular}{|c|c|c|c|c|c|c|}
\hline \multirow[t]{2}{*}{ Variable } & \multicolumn{2}{|c|}{ All } & \multicolumn{2}{|c|}{ PSM sub-sample ${ }^{a}$} & \multicolumn{2}{|c|}{ PSM sub-sample ${ }^{b}$} \\
\hline & Coefficient & $\begin{array}{c}\text { Standard } \\
\text { error }\end{array}$ & Coefficient & $\begin{array}{c}\text { Standard } \\
\text { error }\end{array}$ & Coefficient & $\begin{array}{c}\text { Standard } \\
\text { error }\end{array}$ \\
\hline \multicolumn{7}{|l|}{ Stochastic production function } \\
\hline Constant & $7.72553^{* * *}$ & 0.13213 & $7.70797^{* * *}$ & 0.13438 & $7.70829^{* * *}$ & 0.13398 \\
\hline Capital stock & $0.01602^{*}$ & 0.00834 & $0.01706^{*}$ & 0.00841 & $0.01932^{* *}$ & 0.00843 \\
\hline Land & $0.82966^{* * *}$ & 0.03544 & $0.83659^{* * *}$ & 0.03575 & $0.82988^{* * *}$ & 0.03605 \\
\hline Family labour & $0.08053^{*}$ & 0.04706 & $0.09225^{*}$ & 0.04756 & $0.08744^{*}$ & 0.04698 \\
\hline Wage labour & $0.10479^{* *}$ & 0.04412 & $0.10602^{* *}$ & 0.04456 & $0.10044^{* *}$ & 0.04469 \\
\hline \multicolumn{7}{|l|}{ Inefficiency components } \\
\hline Constant & 1.69674 & 1.55067 & 1.77395 & 1.55325 & 1.65230 & 1.56925 \\
\hline Cooperatives & $-0.88674^{* * *}$ & 0.29322 & $-0.91890^{* * *}$ & 0.29511 & $-1.01719^{* * *}$ & 0.31651 \\
\hline Age & -0.00628 & 0.05240 & -0.00892 & 0.05249 & -0.00679 & 0.05317 \\
\hline Age squared & 0.00002 & 0.00046 & 0.00005 & 0.00046 & 0.00002 & 0.00047 \\
\hline Years of education & 0.00935 & 0.02181 & 0.01325 & 0.02201 & 0.01127 & 0.02230 \\
\hline Years of farming & 0.01834 & 0.02627 & 0.01857 & 0.02649 & 0.02130 & 0.02690 \\
\hline Years of farming squared & -0.00007 & 0.00053 & -0.00006 & 0.00053 & -0.00014 & 0.00054 \\
\hline Age of olive trees & $-0.04219^{* * *}$ & 0.01451 & $-0.04387^{* * *}$ & 0.01460 & $-0.04336^{* * *}$ & 0.01467 \\
\hline Age of olive trees squared & $0.00028^{* *}$ & 0.00014 & $0.00029^{* *}$ & 0.00014 & $0.00029^{* *}$ & 0.00014 \\
\hline Density of olive trees & $-0.00648^{* * *}$ & 0.00257 & $-0.00660^{* * *}$ & 0.00259 & $-0.00618^{* *}$ & 0.00261 \\
\hline Share of irrigated area & 0.00314 & 0.00543 & 0.00169 & 0.00546 & 0.00203 & 0.00551 \\
\hline Distance to nearest oil mill & $0.04253^{* *}$ & 0.02063 & $0.04125^{* *}$ & 0.02053 & $0.04207^{* *}$ & 0.02074 \\
\hline \multicolumn{7}{|l|}{ Variance parameters } \\
\hline$\sigma_{v}^{2}$ & $0.34324^{* * *}$ & 0.05276 & $0.34085^{* * *}$ & 0.05302 & $0.34296^{* * *}$ & 0.05293 \\
\hline $\operatorname{Ln} \sigma_{v}^{2}$ & $-2.13863^{* * *}$ & 0.30739 & $-2.15263^{* * *}$ & 0.31111 & $-2.14028^{* * *}$ & 0.30864 \\
\hline Log-likelihood & -340.1 & & -336.5 & & -331.4 & \\
\hline Number of observations & 350 & & 346 & & 343 & \\
\hline AIC & 716.3 & & 709.1 & & 698.8 & \\
\hline $\mathrm{BIC}$ & 785.7 & & 778.3 & & 767.8 & \\
\hline
\end{tabular}

Notes: *, **, *** indicate significant at the $10 \%$ level, $5 \%$ level, $1 \%$ level, respectively.

${ }^{a}$ The sub-sample was obtained from Kernel matching $(n=346)$.

${ }^{b}$ The sub-sample was obtained from 5 nearest neighbors matching $(n=343)$. 
Table 5 - Estimated coefficients and standard errors of TFP equations.

\begin{tabular}{|l|cc|cc|cc|}
\hline Variable & \multicolumn{2}{|c|}{ All } & PSM sub-sample & \multicolumn{2}{c|}{ PSM sub-sample $^{b}$} \\
\cline { 2 - 7 } & Coefficient & $\begin{array}{c}\text { Standard } \\
\text { error }\end{array}$ & Coefficient & $\begin{array}{c}\text { Standard } \\
\text { error }\end{array}$ & $\begin{array}{c}\text { Coefficient } \\
\text { Standard } \\
\text { error }\end{array}$ \\
\hline Constant & $5.64618^{* * *}$ & 0.61119 & $5.60079^{* * *}$ & 0.61273 & $5.68908^{* * *}$ & 0.61356 \\
Cooperatives & $0.30833^{* * *}$ & 0.09216 & $0.33184^{* * *}$ & 0.09446 & $0.34360^{* * *}$ & 0.09537 \\
Age & 0.00722 & 0.02147 & 0.00787 & 0.02154 & 0.00629 & 0.02166 \\
Age squared & -0.00003 & 0.00019 & -0.00004 & 0.00019 & -0.00002 & 0.00019 \\
Years of education & 0.00163 & 0.00882 & 0.00088 & 0.00887 & 0.00127 & 0.00888 \\
Years of farming & -0.00259 & 0.01046 & -0.00277 & 0.01060 & -0.00380 & 0.01064 \\
Years of farming squared & -0.00005 & 0.00020 & -0.00005 & 0.00020 & -0.00002 & 0.00021 \\
Age of olive trees & $0.01956^{* * *}$ & 0.00586 & $0.02036^{* * *}$ & 0.00590 & $0.02004^{* * *}$ & 0.00589 \\
Age of olive trees squared & $-0.00014^{* *}$ & 0.00006 & $-0.00014^{* *}$ & 0.00006 & $-0.00014^{* *}$ & 0.00006 \\
Density of olive trees & $0.00264^{* * *}$ & 0.00097 & $0.00265^{* * *}$ & 0.00098 & $0.00250^{* *}$ & 0.00098 \\
Share of irrigated area & -0.00274 & 0.00226 & -0.00227 & 0.00229 & -0.00250 & 0.00229 \\
Distance to nearest oil mill & $-0.01784^{* *}$ & 0.00763 & $-0.01715^{* *}$ & 0.00768 & $-0.01692^{* *}$ & 0.00768 \\
& & & & & & \\
F-value & 4.440 & & 4.50 & & & \\
$R^{2}$ & 0.126 & & 0.129 & & 0.127 & \\
Adjusted $R^{2}$ & 0.098 & & 0.100 & & 0.098 & \\
Number of observations & 350 & & 346 & & 343 & \\
\hline
\end{tabular}

Notes: *, **, *** indicate significant at the $10 \%$ level, $5 \%$ level, $1 \%$ level, respectively.

${ }^{a}$ The sub-sample was obtained from Kernel matching $(n=346)$.

${ }^{b}$ The sub-sample was obtained from 5 nearest neighbors matching $(n=343)$.

sis that there are no farm-specific effects $(\boldsymbol{\delta}=0)$ at the $1 \%$ level of significance. The signs of estimated coefficients of SFP are as expected. All parameters are positive and statistically significant. We confirmed a positive effect of these inputs on production. Capital stock has less of an effect on output increase, but land is the most significant factor affecting an increase in output level. A $1 \%$ increase in land area increased output by $0.82 \%$ to $0.83 \%$, while a $1 \%$ increase in capital stock increased output by $0.016 \%$ to $0.018 \%$.

In Table 5, we present OLS results of estimated coefficients and standard errors of the TFP equations. As in the SPF estimations, all sample and new sub-samples were used for the estimation of TFP equations. In the estimated results of inefficiency components of SFP, as expected, the parameter of members of agricultural cooperative is negative and statistically significant at the $1 \%$ level. We also found positive and significant estimated parameters in TFP equations. These results suggest that membership in a cooperative is associated with higher TE and TFP. Age and education of household head and farming years appear to have no impact on TE and TFP, yet the age of olive trees has a significant and non-linear effect. The level of TE increases with age of trees up to about 74 to 75 years, after which it declines. Similarly, the level of TFP reaches its maximum around tree age of 70 to 71 years old. While it depends on cultivars and may be different according to climate condition, several studies on olive production found that the age of trees is a critical factor that affects efficiency and productivity. What is more, an increase in the density of olive trees positively affects TE and TFP. These results suggest adoption of intensive farming has a positive effect on efficiency and productivity. While the intensity of olive farming is affected by cultivar, climate, and geo- 
graphical condition, such as slop of plot, it is one of the major factors affecting productivity. The share of irrigation affects neither TE nor TFP, but the positive effect of increase in density of trees suggests the potential to improve TE and TFP through the adoption of intensive farming. Increasing in distance to the nearest oil mill negatively affects TE and TFP.

\subsection{Average treatment effect on the treated (ATT)}

Table 6 shows the estimated results of ATT of being a cooperative member on TE, TFP, land productivity, and production per tree. The impact is estimated using Kernel and five nearest neighbors matching to ensure robustness. For Kernel matching, we use a rule of thumb bandwidth. We added caliper for the estimation of the nearest five neighbors matching to reduce the mean bias in the balancing test. The width of caliper set equal to 0.25 of the standard deviation of the estimated propensity score (Rosenbaum and Rubin, 1985). Esti- mated ATTs yield similar results regardless of the matching methods. The average TE of cooperative members was estimated at $60.97 \%$ and $61.75 \%$ for Kernel and five nearest neighbors matching, respectively, whereas TE of non-member farms were $50.82 \%$ and $51.23 \%$. More specifically, the estimated ATT suggests estimated TE is 10.16 to 10.52 percentage points higher in members than in non-members. The estimated ATTs of TFP indicate cooperative members realized significantly higher TFP than non-members. Yet, the insignificance of ATT of land productivity and production per tree suggests these productivity measures are indifferent between the two groups. These results show that being a member of a cooperative has a significant and positive effect on TE and TFP, but not on land productivity and production per tree. The estimated TE suggests potential to increase production of Jenin farms by 38.64 to $48.98 \%$, given the current technology and inputs. Our results suggest that for non-members, becoming cooperative members contributes to improving TE by about 10 percentage points.

Table 6 - Impact of being member of cooperative on TE, TFP, land productivity and production per tree (ATT).

\begin{tabular}{|c|c|c|c|c|c|c|}
\hline & \multicolumn{3}{|c|}{$\begin{array}{l}\text { Kernel matching } \\
\text { (bandwidth=0.06) }\end{array}$} & \multicolumn{3}{|c|}{$\begin{array}{l}\text { Five nearest neighbors matching } \\
\quad \text { (caliper }=0.05)\end{array}$} \\
\hline & Members & $\begin{array}{l}\text { Non- } \\
\text { members }\end{array}$ & $A T T$ & Members & $\begin{array}{l}\text { Non- } \\
\text { members }\end{array}$ & $A T T$ \\
\hline TE (\%) & 60.97 & 50.82 & $\begin{array}{r}10.16^{* *} \\
(3.68) \\
{[2.2-2.3]}\end{array}$ & 61.75 & 51.23 & $\begin{array}{r}10.52^{* *} \\
(4.04) \\
{[2.2-2.3]}\end{array}$ \\
\hline TFP & 6.98 & 6.74 & $\begin{array}{r}0.23^{*} \\
(0.12) \\
{[1.7-1.8]}\end{array}$ & 7.00 & 6.75 & $\begin{array}{r}0.24^{*} \\
(0.13) \\
{[1.7-1.8]}\end{array}$ \\
\hline $\begin{array}{l}\text { Land productivity } \\
(\mathrm{kg} / \mathrm{ha})\end{array}$ & 1735.17 & 1510.99 & $\begin{array}{r}224.18 \\
(174.47) \\
\text { [N.A.] }\end{array}$ & 1749.41 & 1477.41 & $\begin{array}{r}272.01 \\
(203.35) \\
\text { [N.A.] }\end{array}$ \\
\hline $\begin{array}{l}\text { Production per tree } \\
(\mathrm{kg} / \text { tree })\end{array}$ & 12.70 & 10.87 & $\begin{array}{r}1.83 \\
(1.29) \\
\text { [N.A.] }\end{array}$ & 12.85 & 10.80 & $\begin{array}{r}2.03 \\
(1.43) \\
\text { [N.A.] }\end{array}$ \\
\hline
\end{tabular}

Notes: figures in the parentheses are bootstrapped standard errors (number of replications $=200) . *, * *, * * *$ indicate significant at the $10 \%$ level, $5 \%$ level, $1 \%$ level, respectively. Figures in square brackets are estimated Rosenbaum bounds for critical level of hidden bias $(\Gamma)$. 


\subsection{Robustness check}

The basic assumption in PSM method is heavily dependent on selection of observables, i.e., the assumption of unconfoundedness or conditional independence assumption (Heckman et al., 1997). In our case, if there are unobserved variables which affect participation in cooperatives and efficiency or productivity simultaneously, PSM estimators are not robust against hidden bias (Rosenbaum, 2002). The ATT would be overestimated if farms that join cooperatives are also more likely to have higher efficiency or productivity. We computed the Rosenbaum bounds for critical level of hidden bias $(\Gamma)$ for sensitivity analysis to check the robustness of estimators against unobservables or hidden bias (Becker and Caliendo, 2007). As shown in Table 6 , the estimated bounds under the assumption of positive hidden bias reach the $10 \%$ level of statistical significance at $\Gamma=$ 1.7 to 2.3 . The results suggest that the odds ratio of being a cooperative member that would alter the results of our statistical inference is 1.7 to 2.2. These results indicate that the significance of ATT on TE or TFP would be sensitive only if the odds ratio of becoming cooperative members by unobserved characteristics is more than $170 \%$ to $220 \%$. Compared with the odds ratio of observed characteristics, these estimated critical values of odds ratio are relatively high. Hence, we can deduce that the impact of being cooperative members on TE or TFP is less sensitive to unobservables or hidden bias.

We also estimated SFP by using PSM sub-samples $(n=170)$ which consist of all cooperative members under common support (69 farms) and matched non-members (111 farms). Means and standard deviations of TE and TFP including results using this subsample are reported in Table 7. Overall, we found a gap of 10 to 13 percentage points in the average level of TE scores between members and non-members. The difference between average TE between the two groups is statistically significant at the $1 \%$ level. For the overall sample, we estimated the mean value of $\mathrm{TE}$ of cooperative members at $60.63 \%$, which is 10.42 percentage points higher than that of non-members, yet the difference between the two groups slightly increased to 13.17 percentage points when using matched samples. The difference in average level of TFP slightly increases if we use a PSM sub-sample. Thus, the difference in TE and TFP is underestimated if we do not correct for the selection bias. These results are comparable with the estimated ATTs in Table 6.

Table 7 - Means and standard deviations of TE and TFP.

\begin{tabular}{|c|c|c|c|c|c|}
\hline & \multicolumn{2}{|c|}{ Members } & \multicolumn{2}{|c|}{ Non-members } & Difference \\
\hline & Mean & $S D$ & Mean & $S D$ & in means \\
\hline $\operatorname{TE}(\%)^{\mathrm{a}}$ & 60.63 & 17.86 & 50.21 & 21.98 & $10.42^{* * *}$ \\
\hline TE $(\%)^{b}$ & 60.67 & 18.06 & 50.17 & 22.04 & $10.50^{* * *}$ \\
\hline TE $(\%)^{\mathrm{c}}$ & 62.32 & 16.67 & 50.39 & 21.97 & $11.93^{* * *}$ \\
\hline TE $(\%)^{d}$ & 63.41 & 15.97 & 50.24 & 21.41 & $13.17^{* * *}$ \\
\hline TFP $^{\mathrm{a}}$ & 6.96 & 0.58 & 6.69 & 0.75 & $0.27^{* * *}$ \\
\hline $\mathrm{TFP}^{\mathrm{b}}$ & 6.95 & 0.58 & 6.67 & 0.75 & $0.29^{* * *}$ \\
\hline TFP $^{c}$ & 6.99 & 0.55 & 6.68 & 0.75 & $0.30^{* * *}$ \\
\hline TFP $^{d}$ & 7.02 & 0.55 & 6.74 & 0.75 & $0.28^{* * *}$ \\
\hline
\end{tabular}

Notes: *, **, *** indicate significant at the $10 \%, 5 \%, 1 \%$ level, respectively.

${ }^{a}$ All sample was used to estimate TE and TFP $(n=350)$.

${ }^{b}$ The PSM sub-sample obtained from Kernel matching was used to estimate TE and TFP $(n=346)$.

${ }^{c}$ The PSM sub-sample obtained from 5 nearest neighbors matching was used to estimate TE and TFP ( $\left.n=343\right)$.

${ }^{d}$ The PSM sub-sample comprised of all cooperative member farms and matched non-members $(n=180)$ was used to estimate TE and TFP. 


\section{Discussion}

In the national strategy, the Palestinian Government addressed the role of agricultural cooperatives in improving productivity and efficiency of olive production, including post-harvesting activities and marketing. Our empirical result suggests participation in agricultural cooperatives has a positive impact on farm level TE and TFP. The result of a positive effect of cooperative membership on TE is consistent with the finding by Abate et al. (2014) in their empirical study on smallholders of Ethiopia, Jaime and Salazar (2011) in their application on wheat farmers in Chile, and Idiong (2007) who studied small-scale rice farmers in Nigeria's Cross River State. Several studies try to explain how cooperatives affect efficiency and productivity. Abate et al. (2014) interprets that support services of cooperatives, by smoothing access to modern inputs and facilitating extension linkages, contribute to improving TE for Ethiopian smallholders. For yam farmers in Nigeria, Shehu et al. (2010) suggests association membership enables farmers to access loans and productive inputs, which are difficult to obtain individually. Idiong (2007) found information sharing among farmers through farmers' associations have positive impact on TE for small-scale rice farmers in Nigeria. Most studies attribute access to modern inputs, credits, collective knowledge, and availability of extension services as major channels that explain the higher productivity and efficiency of members of cooperatives.

In the case of olive farms in Jenin, as shown in Table 4 and Table 5, farming years, years of schooling, and the expansion of irrigation have a negligible impact on TE and TFP. As a benefit of access to modern inputs, services by cooperatives related to irrigation have a lesser effect, while cooperative members have more access to irrigation than non-members (Table 3 and Table 4). Age of trees is one of the significant factors to improve TE and TFP. In the Andalusian region of Spain, Amores and Contreras (2009) categorized that for new olive trees, the period before they reach 10 years of age is considered the unproductive period. In the case of olive farms in Tunisia, Lachaal et al. (2005) suggests that an increase in the share of productive olive trees
(20-70 years old) contributes to increased efficiency. In our sample of Jenin, the average age of olive trees is 41 , with the youngest being three and the oldest being 100 years old. The finding suggests TE continues to increase on average coming 30 years.

Despite the significance of age of trees, the average of its difference is not statistically significant between the two groups (Table 3). On the other hand, adoption of intensive farming is becoming a common practice among Mediterranean olive famers (Beaufoy, 2001; Amores and Contreras, 2009). Amores and Contreras (2009) developed typologies of olive farming in Andalusia from the points of age of trees, density of trees, land slope, and adoption of irrigation. They consider 140 trees per ha as the cut-off point between traditional and intensive olive farming. Beaufoy (2001) categorized olive farms in Europe that cultivate between 80 and 250 trees per ha as intensive traditional farms, while farms with a density between 200 and 400 trees per ha and mostly irrigated are regarded as intensive modern farming. Our case is comparable with olive farms in Andalusia, since the average density of olive trees in Jenin is 153 per ha, which falls between 80 and 250 trees. In addition, the diffusion of irrigation technique remained at $24.8 \%$ of the sample. Hence, referring to the typology of Beaufoy (2001), olive farms in Jenin can be regarded as intensive traditional farms. In our sample, the increase in density of olive trees is associated with higher TE and TFP. Yet, member farms adopted intensive olive cultivation less than did non-members. As for the location, it is not surprising that farms located far from olive oil mills are less efficient and less productive (Table 4). Similar to the case of rice farmers in Ghana, a long distance to the local market is negatively associated with higher efficiency (Anang et al., 2016). Yet, the distance is not significantly different between the two groups (Table 1). In addition, the average percentage of farms that use fertilizer is slightly higher for members than non-members, but the difference is not significant (Table 1). Members of cooperatives would have easier access to those modern inputs; however, it is difficult to 
explain the difference of TE and TFP due to the benefit of modern inputs.

On the contrary, there are significant differences in inputs of capital, land, and number of olive trees between the two groups (Table 1 and Table 4). While these differences were balanced by the matching, we can infer a channel that may affect TE and TFP from the access to these conventional inputs. First, cooperatives can ease the liquidity constraint through providing credits to member farms. Within olive cultivation in Jenin, four-wheel tractors, cultivators, and rotary tillers are the main agricultural machinery used. Access to such machinery may be difficult for individual smallholders, but it becomes easier if farmers join cooperatives. Increasing access to credits is a merit to becoming a member to invest in agricultural machinery. Second, land-labour ratio is significantly higher for members than non-members (Table 1). It suggests that land area and number of trees to be managed by one labour are more for cooperative member farms. In general, a negative relationship between farm size and level of efficiency or productivity are frequently reported in agricultural production (Bravo-Ureta and Evenson, 1994; Hallam and Machado, 1996; Bozoğlu and Ceyhan, 2007). For olive farms, Tzouvelekas et al. (2001) found larger farms in Greece tend to have lower TE than smaller farms. These evidences imply greater land-labour ratio of cooperative member farms associate with lower TE and TFP. However, this relationship is not relevant for our case. Land size and land area per labour are larger for cooperative members, but their TE and TFP are significantly higher than non-members (Table 1 and Table 6). If the negative relationship exists between farm size and TE or TFP, TE and TFP would be lower for cooperative members. In addition, it should be noted that estimated ATTs of land productivity and production per tree are insignificant (Table 6 ). These results suggest productivity remains constant regardless of land size and number of trees. If the negative relationship between farm size and productivity exited, land productivity and production per tree would have lower for cooperative members than non-members.

Another possibility is a benefit of extension services provided by cooperatives. They may foster efficient farm management that prevents from declining TE and TFP. TE measures the ability of a farm to obtain maximum output from a given set of inputs and technology (Farrell, 1957), but extension services for farmers may contribute to improving this ability. Indeed, the MOA provides land reclamation services through agricultural cooperatives. Cooperative members can obtain the benefits of land reclamation projects, namely, expansion of cultivation area, protection of land and water under Israeli occupation, prevention of abandonment of cultivated land due to the rule of inheritance. Hence, increasing access to land is a merit to becoming a member of cooperatives. In addition, cooperatives provide services for supplying productive seedlings and young olive trees. Cooperative members can benefit from easier access to productive olive seedlings. Hence, increasing access to land and better access to productive olive seedlings through the participation of cooperatives could be a pathway that leads to improved TE and TFP.

We discussed several possible pathways through which cooperatives may affect TE and TFP, but it should be noted that, regardless of cooperative membership, huge inefficiency exists for olive farmers in Jenin. Compared with olive-growing farms in the Mediterranean region, the mean value of TE of farms in Jenin is low. In Greece, TE of olive farms on the island of Crete slightly deviated from $74.9 \%$ to $76.8 \%$ during the period of 1987-1993 and declined from $87.5 \%$ to $63.7 \%$ (Tzouvelekas et al., 1997; Tzouvelekas et al., 1999). TE of olive farms in Spain was estimated at $75.5 \%$ on average from 1999 to 2002 (Lambarraa et al., 2007). Olive farms in Tunisia realized higher TE than Spanish ones, for instance, estimated TE was $83.5 \%$ for olive famers in Mahdia Governorate (19992002) and $82 \%$ for those in Sfax Governorate (1994-1997) (Lachaal et al., 2004; Lachaal et al., 2005). Overall, average level of TE in Jenin is about 14 to 15 percentage points lower than that of Spanish farmers. These results suggest inefficient farms exist in Jenin.

This inefficiency results in low land productivity compared with farms in the Mediterranean region. In our sample of Jenin, the mean value of land productivity remained at $1,660.3 \mathrm{~kg}$ per 
ha. Compared with Israeli olive farms, where the natural environment is nearly identical, the average land productivity ranges from 1,500 to 2,500 $\mathrm{kg}$ per hectare, while it varies and lies between 400 and $2,400 \mathrm{~kg}$ for farmers in the occupied Palestinian territory (UNCTAD, 2015). The East Bank in Jordan, which has similar environmental conditions, realized approximately $2,830 \mathrm{~kg}$ per ha of land productivity (MOA, 2014). We found huge technical inefficiency of olive farms in Jenin, but, conversely, it suggests there is much room to improve. Current government programs put more emphasis on post-harvesting activities and marketing capabilities, but we found the potential to improve in the upstream value chain, namely, production on olive farming. Therefore, one of the challenges is to realize the maximum possible output for olive farmers to improve the general level of productivity.

What is more, the other challenge exists for the low participation rate of cooperatives. As reported by ARIJ (2015), the percentage of membership of farmers belonging to agricultural cooperatives and associations remained at only $33 \%$ in the West Bank. Similarly, in our sample of Jenin, the percentage of farms belonging to cooperatives remained at $21.7 \%$. In addition, 139 farms, $39.7 \%$ of the sample, use cultivated olives domestically. Ninety farms (25.7\%) sell olives on an individual base without either participating in cooperative or transacting with middlemen. Overall, access to export is limited at $1.4 \%$. These figures suggest there is still much room to develop market-oriented farmers from subsistence farming. Encouraging these potential farmers to join cooperatives would contribute to improving their productivity and TE.

\section{Conclusion}

This study investigates the impact of agricultural cooperatives on TE and TFP of olive farms in Jenin of the West Bank by using the SFP approach. Our empirical results suggest that becoming a member of an agricultural cooperative has a positive impact on TE and TFP. The level of TE is maximized with age of trees around 74 to 75 years old, and the level of TFP reaches its maximum around the age of trees at 70 to 71 years old. Adoption of intensive cultivation of olives is positively associated with higher TE and TFP, but remoteness from olive mills is negatively related with them. Controlling for these factors, cooperative membership is significant and positively affects TE and TFP. What is more, having corrected for self-selection bias, the average TE of cooperative members was estimated at $60.97 \%$ and $61.75 \%$, while non-members were $50.82 \%$ and $51.23 \%$ for Kernel and five nearest neighbors matching, respectively. The estimated ATT suggests that joining a cooperative increased TE by 10.16 to 10.52 percentage points. We infer that access to credits, land, productive olive seedlings, and extension services provided by cooperatives are the main channels that affect TE and TFP. Compared with other olive farms in the Mediterranean region, we found huge inefficiency and relatively low labour productivity for olive farms in Jenin. Overall, it is noted that olive-growing farms in Jenin are possible to increase their production by 38.64 to $48.98 \%$ through more efficient use of inputs with given technology. Our results imply participation in agricultural cooperatives is an effective strategy to improve TE and TFP. In view of geopolitical constraints including limited land and water, less access to modern inputs due to the occupation with severe climate condition, together with the famers' low participation rate of cooperative membership, this paper underlines the significance to become cooperative members to improve farms' productivity. It also emphasizes olive-farms in Jenin have the potential to develop their productivity with current production inputs. Our empirical evidence suggests becoming cooperative members is one of the crucial factors to enhance productivity by improving technical efficiency and inducing technical progress.

\section{Acknowledgements}

The author gratefully acknowledged that this research was supported by the Japan Science for Promotion of Sciences (JSPS) under the Grantin-Aid for Challenging Exploratory Research, No. 26590035, entitled: "Research on Promotion and Development of Olive Industries in West Bank for Peace and Prosperity", and was par- 
tially supported by the JST (Japan Science and Technology Agency)-JICA (Japan International Cooperation Agency) Science and Technology Research Partnership for Sustainable Development (SATREPS) project entitled: "Valorization of Bioresources in Semi- and Arid Land Based on Scientific Evidence for the Creation of New Industry". The author thanks the Palestinian Central Bureau of Statistics (PCBS) for their collaboration in implementing the survey of Jenin.

\section{References}

Abate G., Francesconi G.N., Getnet K., 2014. Impact of agricultural cooperatives on smallholders' technical efficiency: Evidence from Ethiopia. Annals of Public and Cooperative Economics, 85(2): 257286. http://hdl.handle.net/10.1111/apce.12035.

Abebaw D., Haile H., 2013. The impact of cooperatives on agricultural technology adoption: Empirical evidence from Ethiopia. Food Policy, 38(C): 82-91. http://www.sciencedirect.com/science/article/pii/S0306919212001030.

Aigner D.J., Lovell C.A.K., Schmidt P., 1977. Formulation and estimation of stochastic frontier production function models. Journal of Econometrics, 6: 21-37. https://doi.org/10.1016/0304-4076 (77)90052-5.

Amores A.F., Contreras I., 2009. New approach for the assignment of new European agricultural subsidies using scores from data envelopment analysis: Application to olive-growing farms in Andalusia (Spain). European Journal of Operational Research, 193(3): 718-729. https://doi.org/10.1016/j. ejor.2007.06.059.

Anang B.T., Bäckman S., Sipiläinen T., 2016. Agricultural microcredit and technical efficiency: The case of smallholder rice farmers in northern Ghana. Journal of Agriculture and Rural Development in the Tropics and Subtropics. 117(2): 189-202. http://nbn-resolving.de/urn:nbn:de:hebis: 34-2016061350415.

Applied Research Institute-Jerusalem (ARIJ), 2015. Palestinian agricultural production and marketing between reality and challenges. Project "Food production-consumption assessment to improve sustainable agriculture and food security in the West Bank-Palestine." Bethelehem: ARIJ. Retrieved from https://www.arij.org/files/arijadmin/IDRC/ finalcermony/2015_05_06_-_Booklet_-_FPCA_ project_-_English_final_-_March_2015-_not_for_ IDRC.pdf.
Artukoglu M.M., Olgun A., Adanacioglu H., 2010. The efficiency analysis of organic and conventional olive farms: Case of Turkey. Agric. Econ-Czech, 56(2): 89-96. http://agris.fao.org/agris-search/search.do? recordID $=$ CZ2010000573.

Baily M.N., Hulten C., Campbell D., 1992. Productivity dynamics in manufacturing plants. Brookings Papers on Economic Activity: Microeconomics, 23(1992): 187-267. https://www.brookings.edu/ wp-content/uploads/1992/01/1992_bpeamicro_ baily.pdf.

Bartelsman E.J., Dhrymes P.J., 1998. Productivity dynamics: U.S. manufacturing plants, 19721986. Journal of Productivity Analysis, 9(1): 5-34. http://hdl.handle.net/10.1023/A:1018383629341 (text/html).

Battese G.E., Coelli T.J., 1995. A model for technical inefficiency effects in a stochastic frontier production function for panel data. Empirical Economics, 20: 325-332. https://doi.org/10.1007/BF01205442.

Beaufoy G., 2001. The Environmental Impact of Olive Oil Production in the European Union: Practical Options for Improving Environmental Impact. Peterborough/Madrid: European Forum on Nature Conservation and Pastoralism / Asociación para el Análisis y Reforma de la Política Agro-rural.

Becker S., Caliendo M., 2007. Sensitivity analysis for average treatment effects. The Stata Journal, 7 : 71-83. http://www.stata-journal.com/article.html? article $=$ st0121.

Bernard T., Taffesse A.S., Gabre-Madhin E., 2008. Impact of cooperatives on smallholders' commercialization behavior: Evidence from Ethiopia. Agricultural Economics, 39(2): 147-161. DOI: 10.1111/j.1574-0862.2008.00324.x.

Binam J.N., Tonye J., Wandji N., 2005. Source of technical efficiency among smallholder maize and peanut farmers in the Slash and Burn agricultural zone of Cameroun. Journal of Economic Cooperation, 26(1): 193-210.

Bozoğlu M., Ceyhan V., 2007. Measuring the technical efficiency and exploring the inefficiency determinants of vegetable farms in Samsun province, Turkey. Agricultural Systems, 94: 649-656. https:// doi.org/10.1016/j.agsy.2007.01.007.

Bravo-Ureta B., Evenson R.E., 1994. Efficiency in agricultural production: The case of peasant farmers in eastern Paraguay. Agricultural Economics, 10: 27-37. https://doi.org/10.1016/01695150(94)90037-X.

Bravo-Ureta B., Greene W.H., Solís D., 2012. Technical efficiency analysis correcting for biases from observed and unobserved variables: An application 
to a natural resource management project. $E m$ pirical Economics, 43(1): 55-72. DOI: 10.1007/ s00181-011-0491-y.

Chebil A., Frija A., Thabet C., 2015. Economic efficiency measures and its determinants for irrigated wheat farms in Tunisia: A DEA approach. New Medit, 14(2): 32-38. https:// newmedit.iamb.it/2015/06/08/economic-efficiency-measures-and-its-determinants-for-irrigated-wheat-farms-in-tunisia-a-dea-approach/.

Chirwa E.W., 2003. Sources of technical efficiency among smallholder maize farmers in southern Malawi. Wadonda Consult Working Paper WC/01/03. Retrieved from: https://www.researchgate.net/ publication/4981929_Sources_of_Technical_Efficiency_among_Smallholder_Maize_Farmers_in_ Southern Malawi.

Coelli T.J., Rao D.S.P., O’Donnell C.J., Battese G.E., 2005. An introduction to efficiency and productivity analysis ( $2^{\text {nd }} \mathrm{ed}$.). New York: Springer.

Cukur F., Saner G., Cukur T., Dayan V., Adanacioglu H., 2013. Efficiency analysis of olive farms: The case study of Mugla province, Turkey. Journal of Food, Agriculture and Environment, 11(2): 317321.

Dehejia R., Wahba S., 2002. Propensity score-matching methods for nonexperimental causal studies. The Review of Economics and Statistics, 84(1): 151-161. http://www.mitpressjournals.org/doi/pdf/ 10.1162/003465302317331982.

Farrell M.J., 1957. The measurement of productive efficiency. Journal of the Royal Statistical Society, Series A, 120: 253-290. https://doi. org/10.2307/2343100.

Francesconi G.N., Heerink N., 2011. Ethiopian agricultural cooperatives in an era of global commodity exchange: Does organisational form matter? Journal of African Economies, 20(1): 153-177. https:// doi.org/10.1093/jae/ejq036.

Getnet K., Anullo T., 2012. Agricultural cooperatives and rural livelihoods: Evidence from Ethiopia. $A n-$ nals of Public and Cooperative Economics, 83(2): 181-198. DOI: 10.1111/j.1467-8292.2012.00460.x.

Hallam D., Machado F., 1996. Efficiency analysis with panel data: A study of Portuguese dairy farms. European Review of Agricultural Economics, 23: 79-93. https://doi.org/10.1093/erae/23.1.79.

Hayami Y., Ruttan V.W., 1985. Agricultural development: An international perspective. Baltimore: The Johns Hopkins Press.

Heckman J., Ichimura H., Todd P.E., 1997. Matching as an econometric evaluation estimator: Evidence from evaluating a job training programme. Review of Economic Studies, 64(4): 605-654. http://hdl. handle.net/10.2307/2971733.

Heckman J., Navarro-Lozano S., 2004. Using matching, instrumental variables, and control functions to estimate economic choice models. The Review of Economics and Statistics, 86(1): 30-57. http://www.mitpressjournals.org/doi/pdf/10.1162/ 003465304323023660.

Huang C.J., Liu J.T., 1994. Estimation of a non-neutral stochastic frontier production function. Journal of Productivity Analysis, 2: 171-180. https://doi. org/10.1007/BF01073853.

Idiong I.C., 2007. Estimation of farm level technical efficiency in smallscale swamp rice production in cross river state of Nigeria: A stochastic frontier approach. World Journal of Agricultural Sciences, 3(5): 653-658.

Iliopoulos C., 2005. New generation cooperatives: the potential of an innovative institutional arrangement for Mediterranean food supply chains, New Medit, 4(1): 14-20. https://newmedit.iamb.it/ edizioni_new_medit,229,229,2005,13,87,new-generation-cooperatives:-the-potential-of-an-innovative-institutional-arrangement-for-mediterranean-food-supply-chains.htm

Imbens G.W., Wooldridge J.M., 2009. Recent developments in the econometrics of program evaluation. Journal of Economic Literature, 47(1): 5-86. http://dx.doi.org/10.1257/jel.47.1.5.

International Labour Organization (ILO), 2014. Findings of the assessment of agricultural cooperatives in West Bank: Challenges and opportunities. Beirut: ILO Regional Office for Arab States. Retrieved from https://www.ilo.org/wcmsp5/groups/public/--ed_emp/---emp_ent/---coop/documents/publication/wcms_566377.pdf.

Jaime M.M., Salazar C.A., 2011. Participation in organizations, technical efficiency and territorial differences: A study of small wheat farmers in Chile. Chilean Journal of Agricultural Research, 71(1): 104-113. DOI: 10.4067/S071858392011000100013.

Jondrow J., Lovell C.A.K., Materov I.S., Schmidt P., 1982. On the estimation of technical inefficiency in stochastic frontier production function model. Journal of Econometrics, 19: 233-238. https://doi. org/10.1016/0304-4076(82)90004-5.

Karagiannis G., Tzouvelekas V., 2001. Self-dual stochastic production frontiers and decomposition of output growth: The case of olive-growing farms in Greece. Agricultural and Resource Economics Review, 30(2): 168-178. https://doi.org/10.1017/ S1068280500001118. 
Kashiwagi K., 2017. Technical Efficiency of Olive-growing Farms in the Northern West Bank of Palestine. Sustainable Agriculture Research, 6(2): 125-140. doi:10.5539/sar.v6n2p125.

Kashiwagi K., Mtimet, N., Zaibet, L., Nagaki, M., 2016. Technical efficiency of olive oil firms under the industrial upgrading programme in Tunisia. New Medit, 15(4): 10-20. https://newmedit.iamb.it/ edizioni_new_medit,229,229,2016,165,1079,technical-efficiency-of-olive-oil-firms-under-the-industrial-upgrading-programme-in-tunisia.htm.

Kumbhakar S.C., Ghosh S., McGuckin J.T., 1991. A generalized production frontier approach for estimating determinants of inefficiency in U.S. dairy farms. Journal of Business and Economic Statistics, 9: 279-286. https://doi.org/10.1080/07350015 .1991 .10509853 .

Lachaal L., Dhehibi B., Chebil A., Karray B., 2004. Technical efficiency measures and its determinants for olive producing farms in Tunisia. In: Emrouznejad A., Podinovski V. (eds.), Data envelopment analysis and performance management. Coventry: Warwick Print, pp. 317-323.

Lachaal L., Karray B., Dhehibi B., Chebil A., 2005. Technical efficiency measures and its determinants for olive producing farms in Tunisia: A stochastic frontier analysis. African Development Review, 17(3): 580-591. https://doi.org/10.1111/j.10176772.2006.00129.x.

Lambarraa F., Serra T., Gil J.M., 2007. Technical efficiency analysis and decomposition of productivity growth of Spanish olive farms. Spanish Journal of Agricultural Research, 5(3): 259-270. https://doi. org/10.5424/sjar/2007053-247.

López A., Marcullo C., 2006. Agricultural cooperatives and economic efficiency. New Medit, 5(3): 1622. https://newmedit.iamb.it/edizioni_new_medit, $229,229,2006,19,71$, agricultural-cooperativesand-economic-efficiency.htm.

Mayen C.D., Balagtas J., Alexander C., 2010. Technology adoption and technical efficiency: Organic and conventional dairy farms in the United States. American Journal of Agricultural Economics, 92(1): 181-195. http://hdl.handle.net/10.1093/ajae/aap018.

Meeusen W., van den Broeck J., 1977. Efficiency estimation from Cobb-Douglas production function with composed error. International Economic Review, 18: 435-444. https://doi. org/10.2307/2525757.

Ministry of Agriculture, State of Palestine (MOA), 2014. The national strategy for olive and olive oil sector in Palestine (2014-2019). Ramallah: Ministry of Agriculture, State of Palestine, September.
Ministry of Agriculture, State of Palestine (MOA), 2015. $5^{\text {th }}$ Meeting of the COMCEC Agriculture Working Group, March $5^{\text {th }}, 2015$, Ankara, Turkey. Retrieved from http://www.comcec.org/en/wp-content/uploads/2016/05/Palestine-3.pdf.

Ozalp A., 2019. Financial analysis of agricultural development cooperatives: A case of western Mediterranean region, Turkey. New Medit, 18(2): 119132. http://dx.doi.org/10.30682/nm1902h.

Palestinian Central Bureau of Statistics (PCBS), 2012a. Agricultural Census 2010, Final Results-West Bank. Ramallah, Palestine.

Palestinian Central Bureau of Statistics (PCBS), 2012b. Agricultural Census 2010, Final Results-Jenin Governorate. Ramallah, Palestine.

Palestinian Central Bureau of Statistics (PCBS), 2017. Census Final Results - Summary Jenin Governorate - Population, Housing and Establishments Census 2017. Ramallah, Palestine.

Rosenbaum P.R., 2002. Observational studies $\left(2^{\text {nd }}\right.$ ed.). New York: Springer.

Rosenbaum P.R., Rubin D.B., 1983. The central role of the propensity score in observational studies for causal effects. Biometrika, 70(1): 41-55. DOI: $10.2307 / 2335942$. https://www.jstor.org/stable/2335942.

Rosenbaum P.R., Rubin D.B., 1985. Constructing a control group using multivariate matched sampling methods that incorporate the propensity score. The American Statistician, 39(1): 33-38. DOI: 10.1080/00031305.1985.10479383.

Rubin D.B., 1977. Assignment to treatment group on the basis of a covariate. Journal of Educational Statistics, 2(1): 1-26. https://doi.org/10.3102/ 10769986002001001.

Shehu J.F., Iyortyer J.T., Mshelia S.I., Jongur A.A.U., 2010. Determinants of yam production and technical efficiency among yam farmers in Benue state, Nigeria. Journal of Social Sciences, 24(2): 143-148. https://doi.org/10.1080/09718923.2010.11892846.

Tzouvelekas V., Giannakas K., Midmore P., Mattas K., 1997. Technical efficiency measures for olive-growing farms in Crete, Greece. International Advances in Economic Research, 3(2): 154-169. https://doi.org/10.1007/BF02294936.

Tzouvelekas V., Giannakas K., Midmore P., Mattas K., 1999. Decomposition of olive oil production growth into productivity and size effects: A frontier production function approach. Cahiers d'économie et Sociologie Rurales, 51: 5-21.

Tzouvelekas V., Pantzios C.J., Fotopoulos C., 2001. Technical efficiency of alternative farming systems: The case of Greek organic and conventional 
olive-growing Farms. Food Policy, 26: 549-569. https://doi.org/10.1016/S0306-9192(01)00007-0.

UNCTAD, 2015. The Besieged Palestinian Agricultural Sector, New York and Geneva: United Nations. Retrieved from https://unctad.org/en/PublicationsLibrary/gdsapp2015d1_en.pdf.

World Bank, 2007. World development report 2008: Agriculture for development. Washington, DC:
World Bank. Retrieved from http://hdl.handle. net/10986/5990.

Wossen T., Abdoulaye T., Alene A., Haile, Feleke M.G., Olanrewaju S.A., Manyong V., 2017. Impacts of extension access and cooperative membership on technology adoption and household welfare. Journal of Rural Studies, 54: 223-233. https:// doi.org/10.1016/j.jrurstud.2017.06.022. 